burn in a few moments and the patient may feel a burning or stinging sensation for one or two or possibly thirty minutes. No dressing is needed. The sheets will adhere to the unbroken skin. They can be kept for weeks if they are moist in a refrigerator; or they may be heated until they are crisp and dry, when they may be stored in a refrigerator. The sheets gave good results when they were applied to indolent, ulcerating war wounds, all of which were infected. Wounds still unhealed after sixty days of other treatment healed in six to nine days. Tissue reactions subsided forty-eight hours after their application. None of the patients was confined to bed and some had shower baths without protection of the plasma sheet. Dry dressings were used at night only.

\section{Taxation and the Social Structure}

THE papers presented before the American Philosophical Society in the symposium on "Taxation and the Social Structure". at its midwinter meeting on February 18-19, 1944, have now been published (Proc. Amer. Phil. Soc., 88, No. 1, 1; 1944). American conditions, with the complex relations between State and Federal taxation, to which there is no exact parallel in Great Britain, make the papers somewhat difficult for British readers to follow. Nevertheless, they are of interest at present in view of the reconsideration of the relations between national and local taxation which is being enforced upon Great Britain by some of the trends towards social security, and also of the bearing of fiscal policy on industrial development, such as the concessions announced by the Chancellor of the Exchequer in relation to obsolescence and research in his last budget speech. In Britain, as in the United States, it is realized that taxation is no passive instrument, but that it inevitably affects the social structure and determines the course of social evolution. Accordingly, taxation policy is an integral part of general social and economic policy, and as such must be recognized in our social philosophy.

Four at least of the papers in this symposium make some contribution to this end, and have a much wider bearing than the issues of Federal and State taxation to which the principles they develop are applied. R. Warren's paper on "The Capitalist and the Social Structure", R. Blough's "Conflict and Harmony in Taxation", H. S. Bloch's "Fiscal Policy and Social Reform as it may affect the Potentialities of the Personal Income Tax", and M. H. Hunter's "The Harmonisation of Fiscal and Social Aims" should make important contributions to clear thinking on these problems. Blough's paper in particular is a challenge to fundamental thought and a plea for further research on the relation of taxation to production and employment.

\section{Fotato Varieties in East Africa}

THE problem of potato varieties suitable for East Africa is discussed by R. E. Moreau, of the Amani Research Institute, in the East African Agricultural Journal, 9 (1944). The inquiry was concerned with the direct physiological effects of climate on the plant and should give some guide to policy when the desired development of the crop is undertaken. The generally accepted view that Solanum tuberosum is an unsuitable crop for hot climates is called in question and the conclusion reached that, given good husbandry, excellent crops of it can be raised in parts of tropical Africa, even though air and soil tempera- tures seem unfavourably high. The short days appear to be of no practical importance, and it is suggested that there may be some countervailing influence in the tropics, such as increased light intensity which accounts for this. The possibility that potatoes of the Solanum andigenum group would do better than United Kingdom varieties of $S$. tuberosum is dismissed on purely climatic grounds, though an exception is made of $S$. phureja, which has the further advantage of possessing a particularly high protein content. It is, however, suggested that United States varieties of $S$. tuberosum merit special trial on the score of their possible better adaptation to heat.

\section{Public Health in Haiti}

IN a recent paper (Bol. Of. San. Panamericana, 23, 299 ; 1944) Dr. Jules Thebaud, director-general of public health in Haiti, states that the public health department in his country employs 542 persons, exclusive of day labourers. Owing to lack of funds, Haiti has hitherto been unable to keep pace in public health works; but it has endeavoured to maintain close relations with the Pan-American Sanitary Office. The population of Haiti is estimated at $3,000,000$; in 1942 there were 44,805 births, 12,416 deaths and 3,298 marriages. The principal causes of death in 1942 were contagious and parasitic diseases (25.9 per cent), digestive diseases (14.6 per cent), genito-urinary diseases $(6 \cdot 8$ per cent) and respiratory diseases, except tuberculosis $(6 \cdot 1$ per cent).

\section{Announcements}

The Lord President of the Council has appointed Mr. W. J. Drummond, Dr. H. L. Guy, Sir William Halcrow and Mr. W. F. Lutyens to be members of the Advisory Council to the Committee of the Privy Council for Scientific and Industrial Research, in succession to Sir Joseph Barcroft, Sir Harold Hartley and Sir Frank Smith, who have retired from the Council on completion of their terms of office.

LoRD Swinton, minister resident in West Africa, has been appointed Minister for Civil Aviation, and Sir William Jowitt to be Minister of Social Insurance (designate).

DR. HARLOW SHapley, director of Harvard Observatory, has been awarded the Order of the Aztec Eagle, third class, the highest decoration of the Mexican Government awarded to non-Mexicans, for his promotion of scientific co-operation between the United States and Mexico, and for his assistance in equipping the National Astrophysical Observatory at Tonanzintla, near Puebla, Mexico.

The forty-ninth annual congress of the SouthEastern Union of Scientific Societies is being held at High Wycombe on October 14. The president-elect, Brigadier F. A. E. Crew, director of biological research at the War Office and professor of social medicine in the University of Edinburgh, will deliver his presidential address on "The Biology of War" at 11 a.m.; sectional presidential addresses will precede this address.

Erratum.-Messrs. Baird and Tatlock (London), Ltd., referring to the paragraph entitled "A New Type of Still" in Nature of September 23, p. 393, state that in line 15 "motor" should read "heater", and that the results quoted are the average of a number of experiments. 